\title{
Kamienne bruki Górnego Miasta w Poznaniu
}

\author{
Janusz Skoczylas, Lukasz Skoczylas
}

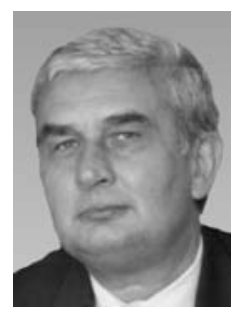

J. Skoczylas

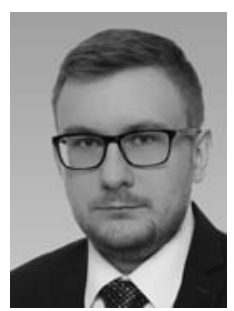

Ł. Skoczylas

Stone pavements of the Upper City in Poznań. Prz. Geol., 68: 774-779; doi: 10.7306/2020.33

A b s tra ct. The article presents several examples of historical fragments of streets of Poznan in the so-called Upper City with preserved granite gutters, stone pavements with cube dimensions $18 \times 20 \mathrm{~cm}$ and $10 \times 20 \mathrm{~cm}$. Attention was also paid to the presence of setts made of basalt basin, as well as to the roads paved with fieldstone. These increasingly rare fragments of metropolitan streets should be subject to historical and architectural protection. They should be treated as the historic fabric of every city with a long and significant tradition.

Keywords: cobblestone, paving stone, flagstone, curb stone, stone road and pavement surfaces

Na Górnym Mieście w Poznaniu zachowały się do dziś liczne przykłady starych bruków. Są one godne uwagi i zainteresowania, a przede wszystkim zachowania. Dotyczy to przede wszystkim fragmentów nawierzchni Alei Marcinkowskiego oraz ulic 23 Lutego, Młyńskiej, Wysokiej, Paderewskiego i Ludgardy (ryc. 1). Bruki te cechują się ciekawym ułożeniem kostek, ich zróżnicowanym składem petrograficznym, a towarzyszą im dawno już zapomniane kamienne rynsztoki. Dzieje oraz współczesną charakterystykę stosowania kamiennych bruków na terenie okolic Starego Rynku w Poznaniu częściowo zasygnalizowano we wcześniejszej pracy (Skoczylas, Skoczylas, 2020). Celem niniejszego artykułu jest charakterystyka kamiennych bruków na obszarze Górnego Miasta w Poznaniu, rozbudowywanego w poczatkach XIX w. na podstawie projektu urbanistycznego władz pruskich. Opisano w nim nowożytne zastosowanie skał oraz leizny bazaltowej jako materiału brukarskiego, a także ocalałe zabytki brukarskiej sztuki kamieniarskiej, godne uchronienia od proponowanego zastąpienia ich nowymi brukami maszynowymi lub nawierzchnią innego rodzaju.

\section{KAMIENNE BRUKI W MIASTACH POLSKICH - ZARYS HISTORYCZNY}

Pierwszym najpowszechniejszym materiałem utwardzającym nawierzchnię w polskich miastach było prawdopodobnie drewno (Dymaczewski, 1961; Kaniecki, 2004). Analiza materiałów będących rezultatem wykopaliskowych prac archeologicznych pozwala przypuszczać, że prawdopodobnie już w końcowym wczesnym średniowieczu do utwardzania ulic na Ostrowie Tumskim w Poznaniu stosowano okruchy skalne przywleczone przez lądolód ze Skandynawii, nazywane dziś eratykami lub narzutniakami (Górska-Zabielska, 2008). W latach 1939 oraz 1950-1953 przy ul. Wieżowej 2-4 w Poznaniu odkryto w tzw. trzecim poziomie osadniczym, datowanym na początek XI w., bruk kamienny o nierozpoznanej wówczas funkcji (Dymaczewski, 1961; Kaniecki, 2004). Inne badania

Ryc. 1. A - Obszar badań - kolorem czarnym oznaczono opisywane fragmenty ulic, kolorem szarym pozostałe ulice; $\mathbf{B}$ - umiejscowienie obszaru badań w granicach administracyjnych współczesnego Poznania

Fig. 1. A - Research area - the described parts of streets are marked as black, other streets are marked as grey; $\mathbf{B}$ - location of the research area within the administrative boundaries of contemporary Poznań

ski, 1961; Kaniecki, 2004). Inne badania

\footnotetext{
${ }^{1}$ Wydział Nauk Geograficznych i Geologicznych, Uniwersytet im. Adama Mickiewicza w Poznaniu, ul. Bogumiła Krygowskiego 12, 60-680 Poznań; skocz@amu.edu.pl

${ }^{2}$ Wydział Socjologii, Uniwersytet im. Adama Mickiewicza w Poznaniu, ul. Augustyna Szamarzewskiego 89, 60-568 Poznań; luke@amu.edu.pl
} 
archeologiczne wykazały, że w połowie XIII w., po lokacji Poznania na wschodnim brzegu Warty, część ulic wjazdowych na teren rynku miała kamienną nawierzchnię w postaci prymitywnego bruku, składającego się z niewymiarowych narzutniaków, nazywanych w XIX w. kamieniami polnymi (Kaniecki, 2004).

$\mathrm{W}$ wielkich miastach na ziemiach polskich kamienne bruki pojawiły się powszechnie w drugiej połowie XIV w. W Krakowie do robót brukarskich wykorzystywano początkowo lokalne wapienie jurajskie (oksford) facji skalistej (Weber-Kozińska, 1960; Duda, 1998; Rajchel, 2005). We Wrocławiu bruki układano prawdopodobnie z granitów eksploatowanych w najbliższej okolicy, być może sprowadzano je z rejonu Sobótki (Weber-Kozińska, 1960). Z kolei w Poznaniu były to wyłącznie eratyki. Podobnie w Warszawie do brukowania ulic zastosowano eratyki, choć nastąpiło to dopiero w XVI w. (Weber-Kozińska, 1961; Sygietyńska, 1978).

Należy zaznaczyć, że prawdopodobnie większość pozostałości bruku kamiennego znajduje się w polskich miastach kilka metrów pod współczesną nawierzchnią i w związku z tym, mimo licznych i dobrze udokumentowanych prac archeologicznych, nie może stanowić atrakcji turystycznej lub obiektu edukacyjnego.

\section{KAMIENNE BRUKI GÓRNEGO MIASTA W POZNANIU}

W końcu XVIII w., po całkowitym zagospodarowaniu terenów w granicach średniowiecznych umocnień, dalszy urbanistyczny rozwój Poznania był planowany na terenach zachodnich, początkowo przez Komisję Dobrego Porząd$\mathrm{ku}$, a później przez władze pruskie. Wynikało to z jednej strony z ograniczeń geograficznych (Warta na wschodzie, Wzgórze Winiarskie na północy), lepszych warunków hydrologicznych (wyższe położenie zabezpieczające przed powodziami), a w późniejszym okresie także $\mathrm{z}$ chęci otwarcia miasta na nową stolicę - Berlin. Ostatecznie w 1794 r. ukończono szczegółowy plan urbanistyczny, którego główne założenia stworzył David Gilly (Ostrowska-Kębłowska, 2009). Był to jeden $\mathrm{z}$ wielu podobnych planów realizowanych na terenach pod władaniem państw niemieckich (Monachium - 1795 r., Hamburg - 1804 r., Wrocław 1806 r., Wiedeń - 1816 r.), choć względem większości z nich wcześniejszy (Ostrowska-Kębłowska, 2009).

Zmiany urbanistyczne w Poznaniu przybrały szczególną formę po 1803 r., gdy miasto poważnie ucierpiało w wyniku pożaru. Odbudowę postanowiono przeprowadzić według wzorów zachodnich, sprawdzonych m.in. w Paryżu i Londynie (Ostrowska-Kębłowska, Skuratowicz, 1994). Realizację tych planów przerwały najpierw wojny napoleońskie, a później przekształcenie Poznania w 1828 r. w miasto twierdzę (Pałat, 2011). Niestety, nie pozostawiono wyczerpujących informacji na temat prac brukarskich w tym okresie. Wiadomo natomiast, że do 1890 r. ulice Poznania brukowano w sposób dość prymitywny, prawie wyłącznie eratykami (Nowakowski, 1929; Skoczylas, Skoczylas, 2020). Duże zmiany w tej materii zaszły ok. 1900 r., kiedy do miasta przyłączono wiele nowych dzielnic. Potrzeba połączenia nowych części Poznania z centrum zaowocowała wieloma pracami brukarskimi, w tym m.in. poszerzaniem lub przebrukowaniem ulic na interesującym nas terenie Górnego Miasta (Nowakowski, 1929; Skoczylas, Skoczylas, 2020).

\section{Aleje Marcinkowskiego}

Na szczególną uwagę zasługuje główny, reprezentacyjny trakt Górnego Miasta - Aleje Karola Marcinkowskiego, dawniej ulica Wilhelmowska, wytyczona na wzór berlińskiej Unter den Linden (Trzeciakowski, 1994; Ostrowska-Kębłowska, 2009). Aleje te tworzą dwie jezdnie (wschodnia i zachodnia) przedzielone szerokim pasem zieleni. Zostały one wytyczone na początku XIX w., a nową nawierzchnię otrzymały w latach 1890-1899. Na całej długości są pokryte kamiennym brukiem o przeciętnych wymiarach $18 \times 20 \mathrm{~cm}$.

Pierwotny fragment brukowego pokrycia stanowią przede wszystkim granitowe rynsztoki, które - nieco juz zniszczone i zwietrzałe - zachowały się po obu stronach pasa zieleni (ryc. 2). Ich wartość zabytkowa i ekspozycyjna nie została jednak zauważona i doceniona. Być może dlatego ciągle stanowią dowód trwałości dawnej sztuki kamieniarstwa i drogownictwa. Godny zachowania jest również fragment wschodniego pasma alej, na odcinku pomiędzy ulicami 23 Lutego i Paderewskiego, na którym brukowa nawierzchnia została wykonana z ciemnoczerwonych kostek granitów i gnejsów, początkowo ułożonych rzędowo. Jednak na skrzyżowaniu z ul. Paderewskiego ta sama kostka jest ułożona w ,jaskółczy ogon”, czyli skośnie do krawędzi ulicy (Ratajczak, 1936; Hałas, 1933). Takie ułożenie kostek brukowych jest możliwe, jeżeli przy krawężnikach zostaną ułożone kostki w kształcie pięciokąta, określane jako „czapki biskupie” (ryc. 2, 3). Wskutek licz-

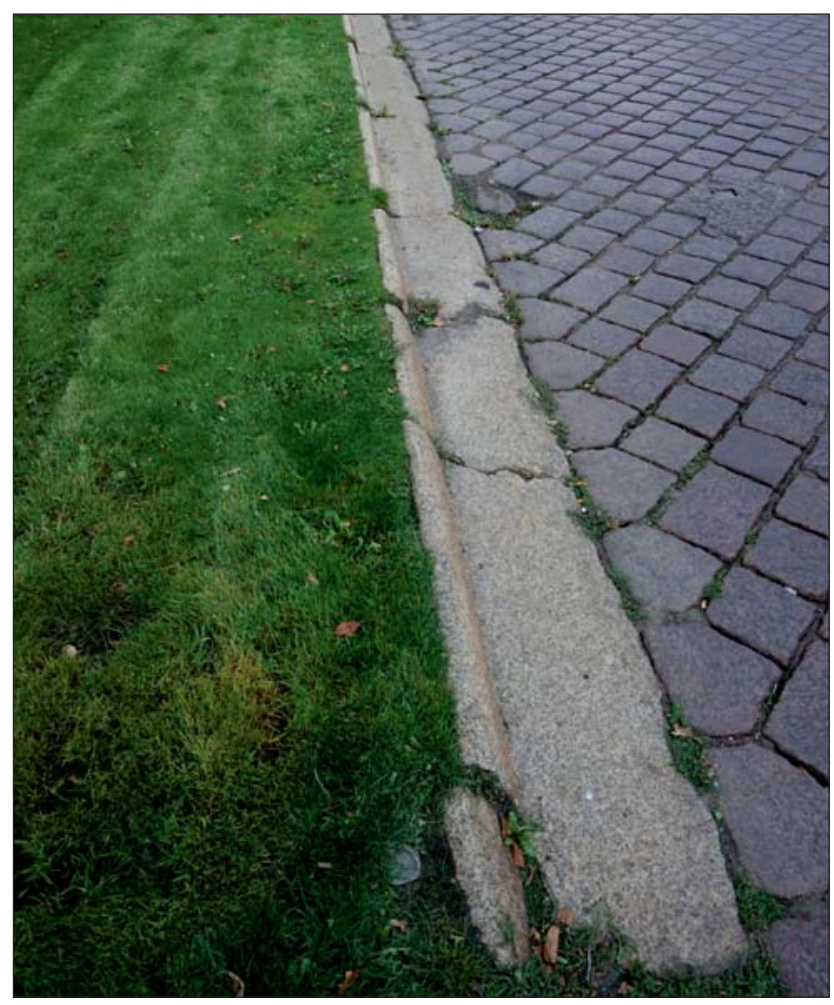

Ryc. 2. Aleje Marcinkowskiego, jezdnia wschodnia między ul. 23 Lutego a ul. Paderewskiego - granitowe rynsztoki, wzdłuż nich kostka w kształcie tzw. czapek biskupich i ułożenie kostki w „jaskółczy ogon”. Wszystkie fotografie J. Skoczylas

Fig. 2. Marcinkowskiego Avenue, east road between February $23^{\text {rd }}$ Street and Paderewski Street - granite gutters, so-called episcopal hats and the setts arranged in dovetail. All photographs by J. Skoczylas 
nych zmian i przebrukowań na wysokości starego budynku Muzeum Narodowego odsłania się fragment bruku będący przykładem prac nad poszerzeniem tego odcinka alej, wykonany z kostek szarego granitu (innego innego niż granit rynsztoków), gnejsu i kwarcytu (ryc. 3). Wprawdzie zachowano ukośny układ kostek brukowych, jednak bez pięciokątów, czyli bez „czapek biskupich”. Zamiast nich zastosowano ścięte kostki o trójkątnej powierzchni. Zasadniczy materiał skalny wschodniej jezdni alej - czyli ciemnoczerwone kostki granitów i gnejsów - nawiązuje składem i ułożeniem do prostopadłego w stosunku do niej fragmentu ulicy 23 Lutego.

\section{Ulica 23 Lutego}

$\mathrm{Na}$ odcinku od ul. Kramarskiej do Alej Marcinkowskiego nawierzchnię ul. 23 Lutego wykonano z ciemnoczerwonych kostek granitowych i gnejsowych. Wprawdzie pierwszych 11 rzędów ułożono w formie kostki rzędowej, to jednak następny fragment ulicy ma ukośne ułożenie kostek brukowych, z wykorzystaniem ,czapek biskupich”. Takie ułożenie, mimo późniejszego posadowienia torów tramwajowych, ciagnie się i utrzymuje do skrzyżowania ze wschodnim pasmem Alej Marcinkowskiego. Krawężniki

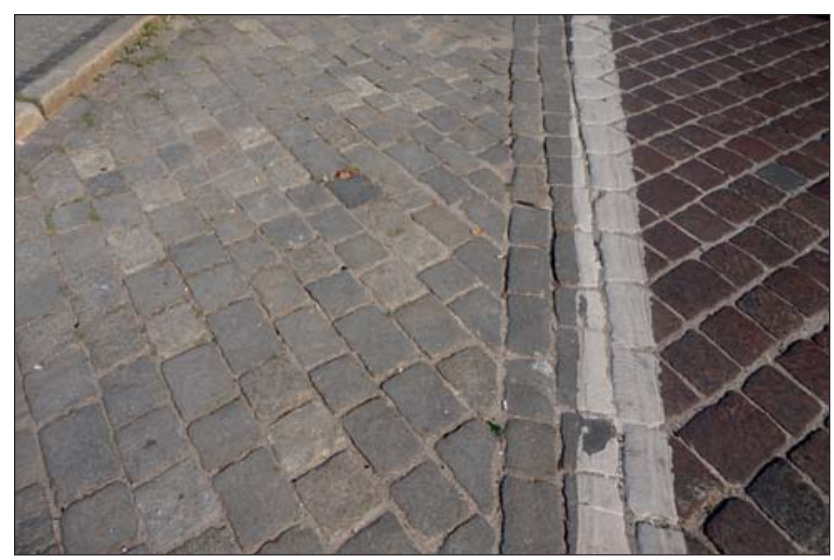

Ryc. 3. Aleje Marcinkowskiego, jezdnia wschodnia w miejscu rozszerzenia przy Muzeum Narodowym - bruk z szarych kostek granitu, gnejsu i kwarcytu

Fig. 3. Marcinkowskiego Avenue, east road, widening the terrace next to the old building of the National Museum - grey granite, gneiss and quartzite setts

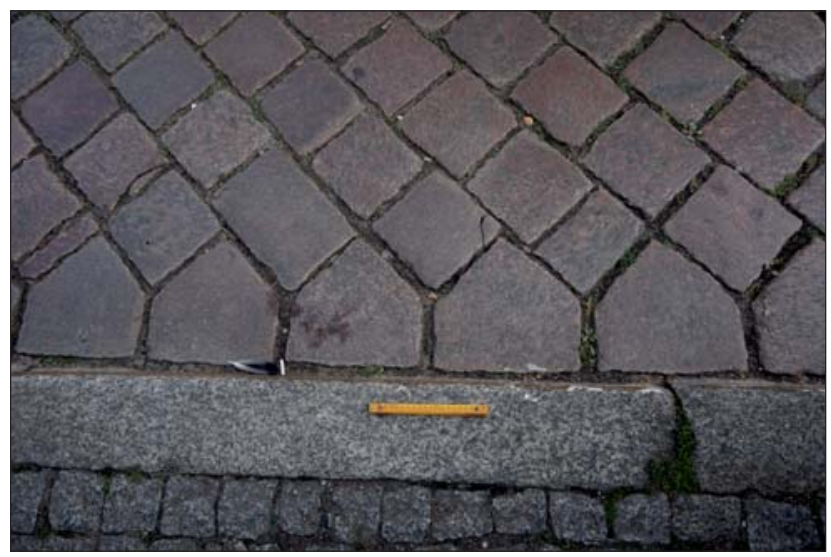

Ryc. 4. Ulica 23 Lutego - „czapki biskupie” przy krawężniku z szarego granitu i bruk ułożony w ,jaskółczy ogon"

Fig. 4. February $23^{\text {rd }}$ Street - so-called episcopal hats on the grey granite curbs and dovetail

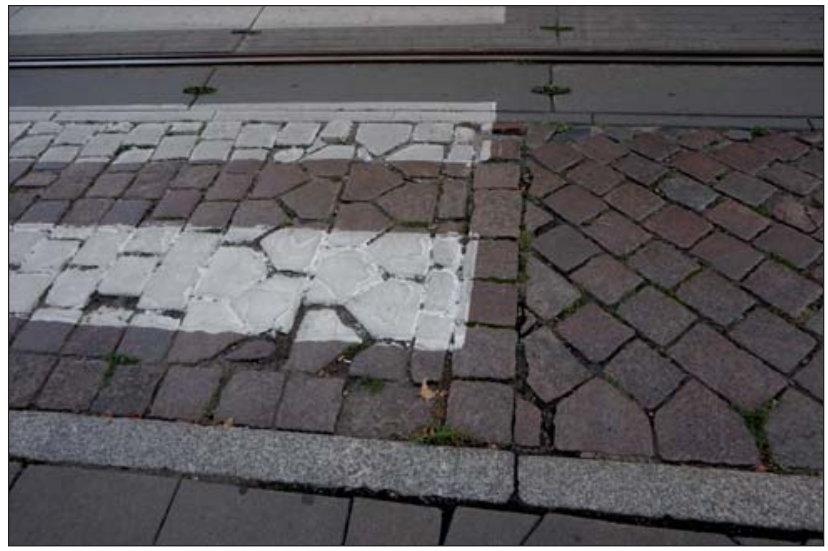

Ryc. 5. Ulica 23 Lutego - oryginalne i wtórne (?) wykorzystanie „czapek biskupich"

Fig. 5. February $23^{\text {rd }}$ Street - original and secondary (?) use of the so-called episcopal hats

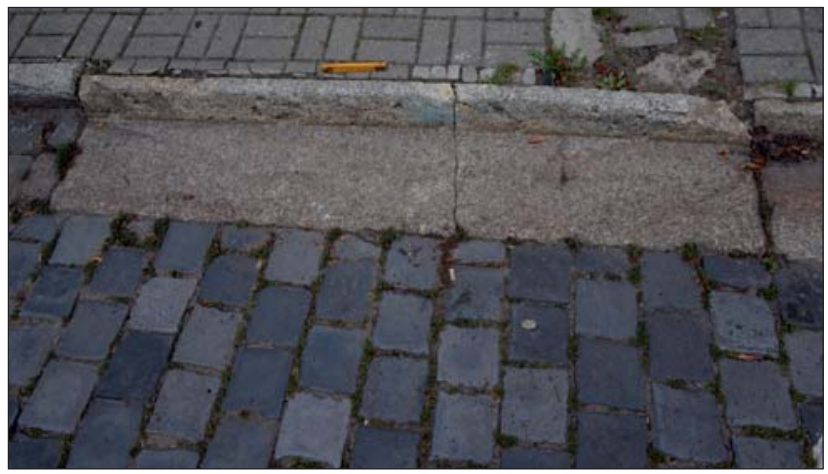

Ryc. 6. Ulica Młyńska między ul. F. Nowowiejskiego a pl. Ratajskiego - kostka brukowa z tzw. leizny bazaltowej, granitowe rynsztoki oraz współczesna kostka chodnikowa

Fig. 6. Młyńska Street between Nowowiejski Street and Ratajski Square - basalt basin setts, granite gutters and modern pavement blocks

wykonano natomiast z szarego granitu (ryc. 4, 5). Ze względów estetycznych niekorzystnym zjawiskiem jest współczesne zamalowywanie zabytkowej kostki brukowej (najczęściej białą farbą). Takie oznaczanie nawierzchni ulic, niezbędne dla usprawnienia komunikacji pieszych i pojazdów, kontrastuje niestety z zabytkową infrastrukturą drogową (ryc. 3, 5).

\section{Ulica Młyńska}

$\mathrm{Na}$ niewielkim odcinku ulicy Młyńskiej, od skrzyżowania z ul. Nowowiejskiego do pl. Ratajskiego, zachowały się w Poznaniu unikalne, granitowe rynsztoki. Ponadto na tym odcinku zachowała się kostka brukowa wykonana $\mathrm{z}$ tzw. leizny bazaltowej (ryc. 6). Moda na kładzenie takiej nawierzchni panowała w latach 20. XX w. Leizna bazaltowa to stop bazaltu, podgrzany i doprowadzony do stanu półpłynnego, z którego formowano odpowiednie kostki. Zaprzestano jej stosowania, ponieważ konie i samochody bardzo się na niej ślizgały, szczególnie w czasie deszczu. Warto jednak dodać, że podobne problemy, choć w mniejszym zakresie, stwarzały także bruki kamienne. Urzędnicy Poznania zasięgnęli w tej sprawie rady specjalistów z Królewca, którzy doradzali, żeby newralgiczne miejsca posypywać warstwą żwiru, nie 
przekraczając jednak pewnej wysokości, tak aby tramwajom umożliwić swobodny przejazd (Myschor, 2010).

\section{Ulica Wysoka}

Fragment ulicy Wysokiej o przebiegu wschód-zachód, łączący niżej położony pl. Wiosny Ludów z ul. Piekary, stanowi wyjątkowo interesujący przykład różnych etapów budowy i poprawiania ulicy. Idąc od pl. Wiosny Ludów w górę zauważamy pierwsze 33 rzędy bruków wykonanych z kostki kwarcytowej. Dalej jednak reszta nawierzchni ulicy jest wykonana z tzw. kocich łbów, czyli nieobrobionych narzutniaków. Po południowej stronie tej ulicy ciągną się nieprzerwanie granitowe rynsztoki, wzdłuż których ułożono jeden rząd kostek brukowych, najczęściej granitowych (ryc. 7). Z kolei po północnej stronie ciag rynsztoków jest kilkakrotnie przerywany przez pozostałości po doraź-

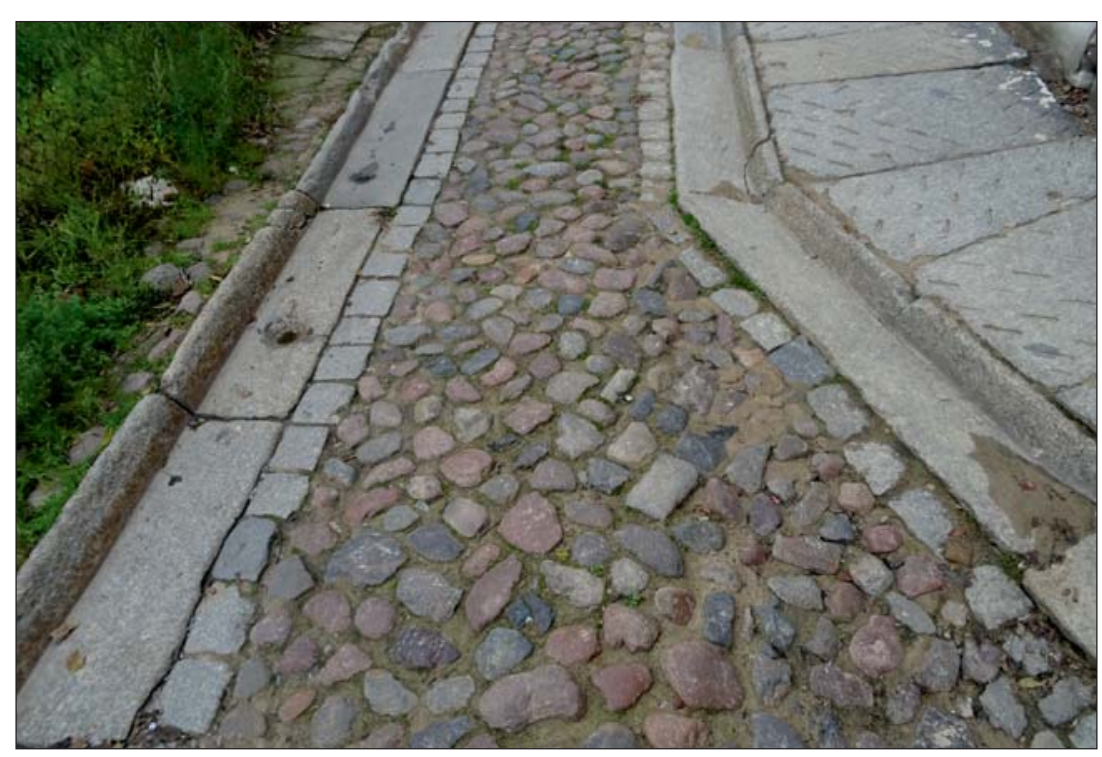

Ryc. 7. Ulica Wysoka - bruk z nieobrobionych narzutniaków i unikalne elementy sztuki brukarskiej - płyty chodnikowe z reliefem antypoślizgowym

Fig. 7. Wysoka Street - pavement of untreated erratic stones and unique elements of paving art - paving slabs with anti-skid relief nych naprawach. Również po północnej stronie ciagną się płyty granitowe, pełniące pierwotnie zapewne funkcję chodnika dla pieszych. Mają one charakterystyczne żłobienia, ułatwiające poruszanie się pod górę, szczególnie w trudnych warunkach atmosferycznych (ryc. 7).

\section{Ulica Paderewskiego}

Ulica Ignacego Paderewskiego łączy Stary Rynek z Alejami Marcinkowskiego. W pierwotnym średniowiecznym układzie Starego Miasta ulica nie istniała, wytyczono ją dopiero w 1838 r., do czego było konieczne nie tylko wyburzenie murów miejskich, ale także XV-wiecznych zabudowań mieszkalnych. Stanowi ona najprostszy i najwygodniejszy trakt pomiędzy Starym a Górnym Miastem. Obecny stan bruków na tej ulicy to efekt przebrukowania z 1930 r. (Czarnecki, 1987). Nawierzchnia jest wykonana z szarego granitu, jednak można zauważyć również fragmenty nawierzchni z ciemnoczerwonych kostek granitów i gnejsów. Przy krawężnikach z szarego granitu po obu stronach drogi są rzędy bruków wykonane $\mathrm{z}$ bazaltów. Prawdopodobnie miały one spełniać funkcje rynsztokowe. Chodniki po obu stronach wykonano z betonowych płyt, wokół których położono od Rynku do ul. Sierocej drobną kostkę, głównie granitową, a od ul. Sierocej do pl. Wolności kostkę głównie kwarcytową (ryc. 8).

\section{Ulica Ludgardy (od ul. I. Paderewskiego)}

Ulica księżnej Ludgardy Meklemburskiej, wytyczona pod koniec XIX w., łączy ulicę Paderewskiego z Górą Przemysła. Jej nawierzchnia jest pokryta kostką granitową, najczęściej kwadratową, o złocisto-brązowawym zabarwieniu. Spotyka się także szare gnejsy. Duże płyty chodnikowe zostały wykonane $\mathrm{z}$ szarego granitu i otoczone drobnymi kostkami wapienia, bazaltu, granitu oraz kwarcytu (ryc. 9). Również krawężniki są wykonane z granitu.

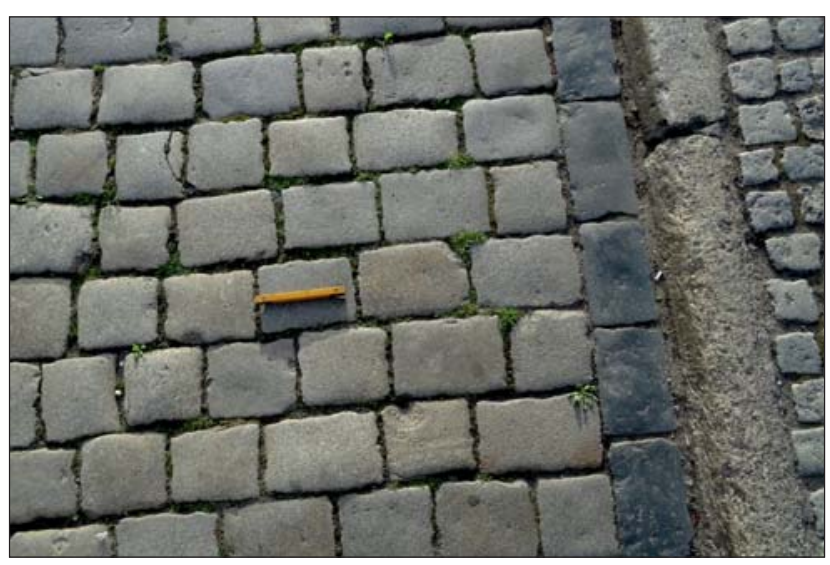

Ryc. 8. Ulica Paderewskiego - kostka granitowa, pas kostki bazaltowej, granitowe krawężniki, drobna kostka na chodniku, głównie kwarcytowa

Fig. 8. Paderewskiego Street - granite cube, a strip of basalt cube, granite curbs, small mainly quartzite cube on the pavement

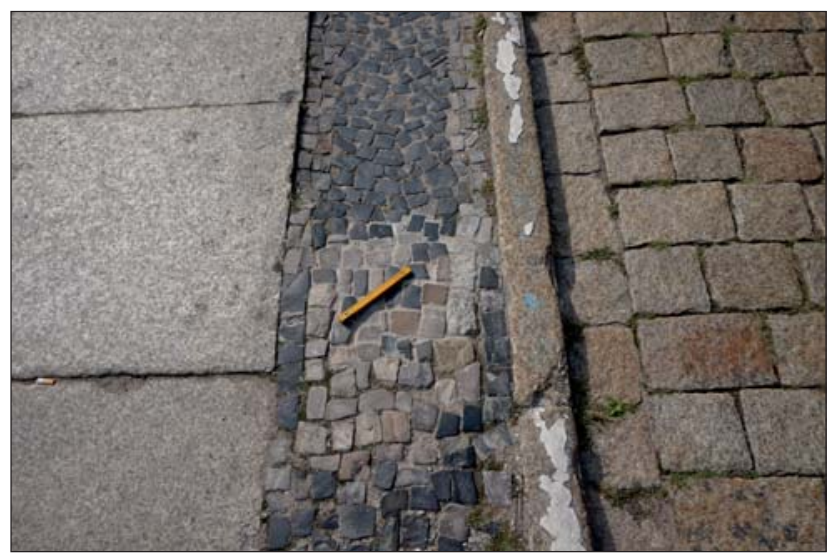

Ryc. 9. Ulica Ludgardy - płyty chodnikowe z szarego granitu; kostka z wapienia, bazaltu, granitu i kwarcytu; granitowa kostka krawężnikowa i na jezdni

Fig. 9. Ludgardy Street - grey granite paving slabs; cube of limestone, basalt, granite and quartzite; granite cube of the curb and the road 


\section{PROWENIENCJA SUROWCÓW SKALNYCH BRUKÓW GÓRNEGO MIASTA}

Analiza kamiennego wystroju wybranych ulic Górnego Miasta w Poznaniu prowadzi do wniosku, że niemal do końca dziewiątej dekady XIX w. podstawowym materiałem skalnym poznańskich bruków, jeżeli nie jedynym, były eratyki, a więc skandynawski materiał skalny przywleczony na ziemie Niżu Polskiego przez lądolody. Poprzez zbieractwo i lokalną eksploatację gromadzono je, niekiedy częściowo obrabiano i wykorzystywano do utwardzania dróg oraz placów.

Rozwój linii kolejowych w drugiej połowie XIX w. spowodowal, że do Prus i na ziemie zaboru pruskiego zaczęto masowo sprowadzać skały wydobyte i obrobione w Skandynawii, przede wszystkim w postaci kostki brukowej. Były to głównie granity i gnejsy, ale także sjenity, dioryty, gabra i diabazy (Król i in., 2004). Wyniki badań petrograficznych wskazuja, że w Poznaniu preferowano brukarskie wykorzystanie kostek wykonanych z granitów i gnejsów barwy czerwonej. Tymi brukami wykładano ulice o największym znaczeniu dla miasta.

Wzrost znaczenia komunikacji kolejowej umożliwił także sprowadzanie surowca skalnego z Dolnego Śląska, głównie szarych granitów. Zdecydowana większość krawężników i płyt chodnikowych jest wykonana z granitów eksploatowanych w rejonie Strzegomia, Strzelina i Strzeblowa. Jednak niektóre płyty chodnikowe oraz granitowe rynsztoki przypominają raczej granity z Žulowej - po niemiecku Friedberg (Sylwestrzak, Kachnic, 2010; Skoczylas, Skoczylas, 2020). Z Dolnego Śląska sprowadzano także bazalty i w niewielkich ilościach granit karkonoski (Skoczylas, Skoczylas, 2020).

Wobec zmiany granic po odzyskaniu niepodległości po I wojnie światowej, a więc i zmiany dostępu do złóż surowców skalnych, zapotrzebowanie na kostkę brukową starano się uzupełnić granitoidami z Wołynia, a nawet z Tatr (Nowakowski, 1929). Z kolei bazalty zamiast z Sudetów sprowadzano z kamieniołomów w Janowej Dolinie i Berestowcu (Skalmowski, 1937; Nieć, 2002; Skoczylas, Skoczylas, 2020). Bruki bazaltowe opisywane z ulicy Paderewskiego pochodzą z Wołynia.

W okresie międzywojennym brak dostępu do wystarczająco dużych złóż granitoidów był przyczyną wykorzystywania w Poznaniu kwarcytów eksploatowanych w okolicach Zakopanego (prawdopodobnie w kamieniołomie nad Capkami), w którego okolicach produkowano kostki brukowe (Kotański, 1971).

\section{PRZYSZLOŚĆ BRUKÓW GÓRNEGO MIASTA}

Wobec braku satysfakcjonujących źródeł historiograficznych można przyjacc, iż obecny stan bruków poznańskiego Górnego Miasta jest najprawdopodobniej efektem licznych prac remontowo-modernizacyjnych końcówki wieku XIX i początku XX. Nie zmniejsza to ich wartości jako zabytku i elementu dziedzictwa kulturowego. Warto jednak zwrócić uwage, że układ bruków na Starym Mieście wyraźniej obrazuje zmiany rozwojowe tkanki miejskiej, wskazując np. lokalizację średniowiecznych murów. Brak tego typu świadectw na Górnym Mieście sprawia, że najbardziej interesujące i godne zachowania wydają się prawdopodobnie najstarsze elementy obecnej tam nawierzchni kamiennej, jak granitowe rynsztoki na ulicy Wysokiej, Młyńskiej i w Alejach Marcinkowskiego. W tej części mia- sta stan bruków jest lepszy niż na Starym Mieście, toteż kwestia ich rewaloryzacji nie wydaje się aż tak paląca. Mimo to ich przyszłość budzi niepokój, szczególnie w kontekście planów dotyczących remontu nawierzchni Starego Rynku, usytuowanego w bezpośrednim sąsiedztwie Górnego Miasta. Bruki na Starym Rynku i w jego okolicach, noszące ślady licznych przebrukowań, uzupełnień i napraw, są świadectwem zmian historyczno-technologicznych, które wyróżniają Poznań na tle innych dużych miast w Polsce, dostępnym dla każdego użytkownika tej przestrzeni. Niestety, najprawdopodobniej większość kostki brukowej na Starym Mieście w Poznaniu zostanie wymieniona w czasie prac zaplanowanych na 2022 r. Do zachowania przeznaczono tylko niewielki fragment $\mathrm{w}$ najbliższej okolicy ratusza (Okoński, 2020). Obawiamy się, że podobna przyszłość może spotkać także bruki Górnego Miasta, których wartość jako elementu dziedzictwa kulturowego trudno przecenić.

Naszym zdaniem jedyną akceptowalną formą remontu tego typu historycznej nawierzchni jest ponowne posadowienie znajdującego się tam już bruku, z zachowaniem obecnego układu i ewentualnym punktowym przeszlifowaniem pojedynczych kostek utrudniających poruszanie się. Warto byłoby też wprowadzić oznaczenia lub tablice informacyjne, dzięki którym oryginalne fragmenty brukowej nawierzchni mogłyby się stać atrakcją dla turystów oraz wsparciem edukacyjnym w nauczaniu historii lub w mniejszym stopniu nauk geograficznych i geologicznych. Tablice takie pozwoliłyby także laikom odróżnić oryginalny bruk od współczesnego, stylizowanego na dawny. W Poznaniu istnieją już podobne tablice, wyjaśniające odmienność nawierzchni $w$ miejscu średniowiecznych murów miejskich - zostały one zamontowane bezpośrednio w nawierzchni w 2013 r. jako element systemu identyfikacji miejskiej (Roik, 2013). Proponowane przez nas tablice miałyby jednak pełnić nieco odmienną rolę. Widzimy w nich pomoc edukacyjno-turystyczną, wskazującą na: 1) zmiany technologii stosowanych $w$ drogownictwie; 2) zmiany w wykorzystaniu surowców skalnych spowodowane przez historyczne zmiany polityczne (zabory, odzyskanie niepodległości), technologiczne (powstanie i rozwój kolei) oraz gospodarcze (rozwój handlu międzynarodowego); 3) różnorodność petrograficzną surowców skalnych stosowanych w budownictwie drogowym. Tablice takie mogłyby być pomocą dydaktyczną w czasie lekcji na świeżym powietrzu dla klas o profilu geodezyjno-drogowym lub rozszerzonym profilu historycznym. Warto zaznaczyć, że ze względu na zanieczyszczenie nawierzchni drogowych, raczej nie ma możliwości satysfakcjonującego wykorzystania opisanych bruków w edukacji stricte geologiczno-geograficznej. Aspekt petrograficzny mógłby więc być tylko dodatkiem do wspomnianych głównych zakresów tematycznych (drogowego i historycznego). Tablice te informowałyby turystów o zmianach historycznych zachodzących w Poznaniu, przede wszystkim w wymiarze politycznym i gospodarczym. Powiązanie zmian kamiennej nawierzchni dróg w centrum miasta z przyłączeniem do niego nowych dzielnic pozwalałoby także zinterpretować procesy zachodzące $\mathrm{w}$ mieście jako wzajemnie oddziałujące na siebie elementy szerszej całości. Proponowane przez nas tablice musiałyby tworzyć spójny system, opisujący najciekawsze fragmenty nawierzchni w polu widzenia osoby zwiedzającej poznańskie Górne Miasto. Rozmieszczenie tych tablic powinno być punktowe, w miejscach najciekawszych tematycznie. Kwestia ich szczegółowej 
formy pozostaje do konsultacji ze specjalistami w dziedzinie miejskiej architektury.

\section{LITERATURA}

CZARNECKI W. 1987 - To był też mój Poznań. Wyd. Poznańskie. DUDA J. 1998 - Bruki w krajobrazie Krakowa. Tow. Miłośników Historii i Zabytków Krakowa, Kraków.

DYMACZEWSKI A. 1961 - Badania wykopaliskowe w ogrodzie przy ul. Wieżowej 2-4 w Poznaniu w latach 1950-1953. [W:] Hensel W. (red.), Poznań we wczesnym średniowieczu. t. III, Poznań.

GORSKA-ZABIELSKA M. 2008 - Fennoskandzkie obszary alimentacyjne osadów akumulacji glacjalnej i glacjofluwialnej lobu Odry. Wyd. Naukowe UAM, Poznań.

HAŁAS W. 1933 - Bruki mozaikowe systemu Hałasa. Ostrów Wielkopolski. Wyd. Stefan Rowiński.

KANIECKI A. 2004 - Poznań. Dzieje miasta wodą pisane. Wyd. PTPN, Poznań

KOTAŃSKI Z. 1971 - Przewodnik geologiczny po Tatrach. Wyd. Geol., Państw. Inst. Geol.

KRÓL D., WOŽNIAK P.P., ZAKRZEWSKI L. 2004 - Kamienie szwedzkie w kulturze i sztuce Pomorza. Muz. Arch. w Gdańsku.

MYSCHOR CH. 2010 - Dni cesarskie w Poznaniu. Różne aspekty uroczystych wizyt Wilhelma II w mieście w latach 1902-1913. Wyd. Poznańskie. NIEĆ M. 2002 - Złoża kopalin budowlanych i drogowych. [W:] Ney R. (red.), Surowce skalne. Kamienie budowlane i drogowe. Wyd. IGSMIE PAN, Kraków: 9-140.

NOWAKOWSKI M. 1929 - Budowa i utrzymanie ulic, placów i dróg miejskich. [W:] Księga Pamiątkowa Miasta Poznania. Nakładem Magistratu Stołecznego Miasta Poznania: 547-563.

OKOŃSKI G. 2020 - Wielka przebudowa Starego Rynku w Poznaniu. Głos Wielkopol., 53; https://gloswielkopolski.pl
OSTROWSKA-KEB OWSKA Z 2009 - Architektura i budownictwo w Poznaniu w latach 1780-1880. Wyd. Miejskie, Poznań.

OSTROWSKA-KEBŁOWSKA Z., SKURATOWICZ J. 1994 - Architektura i budownictwo. [W:] Topolski J., Trzeciakowski L. (red.), Dzieje Poznania, t. 2: 1793-1918. PWN, Warszawa-Poznań.

PAŁAT Z. 2011 - Architektura a polityka. Wyd. PTPN, Poznań

RAJCHEL J. 2005 - Kamienny Kraków. Uczelniane Wydawnictwa Naukowo-Dydaktyczne AGH, Kraków.

RATAJCZAK L. 1936 - Brukarstwo. Podręcznik dla pracowników w rzemiośle brukarskim, Poznań.

ROIK M. 2013 - Były mury miejskie, a dzisiaj są tablice. Głos Wielkopol., 197: 5.

SKALMOWSKI W. 1937 - Naturalne materiały kamienne w budownictwie drogowym. Ze szczególnym uwzględnieniem materiałów krajowych. Drog. Inst. Bad. Pol., Warszawa.

SKOCZYLAS J., SKOCZYLAS Ł. 2020 - Kamienne bruki Starego Rynku w Poznaniu jako element dziedzictwa kulturowego. Prz. Geol., 68 (6): 535-539.

SYGIETYŃSKA H. 1978 - Kamień w architekturze i rzeźbie Warszawy. PWN, Warszawa.

SYLWESTRZAK H., KACHNIC J. 2010 - Kamienne tworzywo sztuki. Wyd. Nauk. Uniw. Mikołaja Kopernika, Toruń.

TRZECIAKOWSKI L. 1994 - Aktywność polityczna poznaniaków. [W:] Topolski J., Trzeciakowski L. (red.), Dzieje Poznania, t. 2: 1793-1918. PWN, Warszawa-Poznań,

WEBER-KOZIŃSKA M. 1960 - Górnictwo kamienne. [W:] J. Pazdur (red.). Zarys dziejów górnictwa na ziemiach polskich. t. I. Wydawnictwo Górniczo-Hutnicze, Katowice: 175-198.

WEBER-KOZIŃSKA M. 1961 - Górnictwo kamienne. [W:] J. Pazdur (red.). Zarys dziejów górnictwa na ziemiach polskich. t. II. Wyd. Górniczo-Hutnicze, Katowice: 237- 245.

Praca wpłyneła do redakcji 9.07.2020 r

Akceptowano do druku 23.09.2020 r. 